\title{
Male Thoraco-Omphalopagus Twins
}

\section{Amin El-Gohary $\mathbf{M}^{*}$}

Department of Pediatric Surgery, Burjeel Hospital, Abu Dhabi, UAE

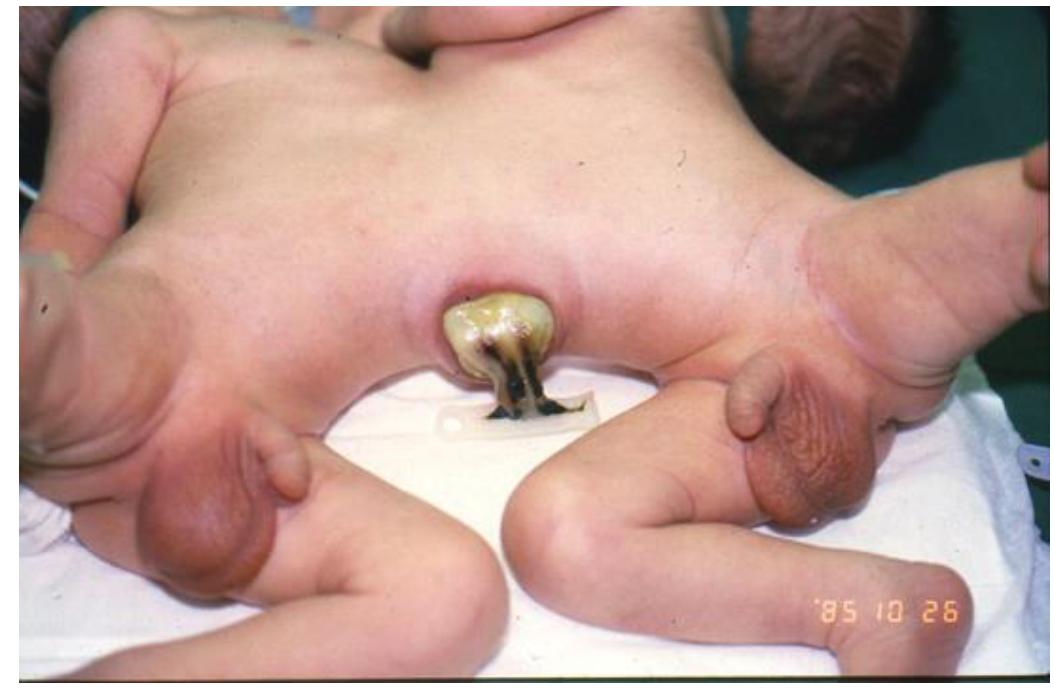

Figure 1: Male thoraco-omphalopagus twins.

Male thoraco-omphalopagus twins were born on 24 October 1985 by Caesarean section (CS) in the second pregnancy of a 28 year-old mother. Their combined weight was $6.7 \mathrm{~kg}$. Examination revealed that they were joined from the lower 6 costal cartilages to the umbilicus, and shared a centrally situated liver (Figure 1), with separate gastro intestinal tracts. Fifty two days with careful planning and several rehearsals, they were successfully separated. The use of intravenous Fluorescence was helpful in delineating the line of fusion and minimizing blood loss during liver separation. The skin defect was bridged with a Silastic membrane under which granulation tissue formed, which was removed 3 months later. They remained well until May 1986, when they presented with weakness and abdominal distension. Both were pale and had massive hepatosplenomegaly. Hematological studies including bone marrow aspiration showed that both had acute lymphoblastic leukemia (ALL-L1), from which both died 3 months later while receiving their third course of chemotherapy. As far as we can ascertain, this is the first case of ALL in conjoined twins.

*Corresponding author: Amin El-Gohary M, FRCS, Professor of Pediatric Surgery, Burjeel Hospital, Abu Dhabi, UAE, Tel: 971506225532; E-mail: amingoh@gmail.com Received February 18, 2015; Accepted February 20, 2015; Published February 25, 2015

Citation: El-Gohary AM (2015) Male Thoraco-Omphalopagus Twins. Gen Med (Los Angel) 3: i101. doi:10.4172/2327-5146.1000i101

Copyright: () 2015 El-Gohary AM. This is an open-access article distributed under the terms of the Creative Commons Attribution License, which permits unrestricted use, distribution, and reproduction in any medium, provided the original author and source are credited. 